\title{
Leadership practices in hospital nursing: a self of manager nurses*
}

\author{
Práticas de liderança em enfermagem hospitalar: uma self de enfermeiros gestores \\ Prácticas de liderazgo en enfermería hospitalaria: una selfie de enfermeros gestores
}

Vânea Lúcia dos Santos Silva', Silvia Helena Henriques Camelo², Mirelle Inácio Soares³, Zélia Marilda Rodrigues Resck, Lucieli Dias Pedreschi Chaves ${ }^{2}$, Fabiana Cristina dos Santos ${ }^{1}$, Laura Andrian Leal ${ }^{1}$

How to cite this article:

Silva VLS, Camelo SHH, Soares MI, Resck ZMR, Chaves LDP, Santos FC, et al. Leadership practices in hospital nursing: a self of manager nurses. Rev Esc Enferm USP. 207;51:e03206. DOI: http://dx.doi.org/10.1590/S1980-220X2016024403206

* Extracted from the dissertation "Práticas de liderança em enfermagem executadas por enfermeiros em organizações hospitalares", Escola de Enfermagem de Ribeirão Preto, Universidade de São Paulo, 2015.

${ }^{1}$ Universidade de São Paulo, Escola de Enfermagem de Ribeirão Preto, Programa de Pós-Graduação em Enfermagem Fundamental, Ribeirão Preto, SP, Brazil.

${ }^{2}$ Universidade de São Paulo, Escola de Enfermagem de Ribeirão Preto, Departamento de Enfermagem Geral e Especializada, Ribeirão Preto, SP, Brazil.

${ }^{3}$ Universidade de São Paulo, Escola de Enfermagem de Ribeirão Preto, Programa Interunidades de Doutoramento em Enfermagem, Ribeirão Preto, SP, Brazil.

${ }^{4}$ Universidade Federal de Alfenas, Escola de Enfermagem, Alfenas, MG, Brazil.

\begin{abstract}
Objective: To assess the frequency of the leadership practices performed by the manager nurses of hospital institutions and their association with the variables of the socioprofessional profile. Method: Cross-sectional, descriptive, correlational study conducted in four hospitals in a city of the state of São Paulo. A sociodemographic questionnaire and the instrument Leadership Practices Inventory were used. Data collection and analysis were based on an exemplary Leadership Practices Model. Results: Eighty-four manager nurses participated in the study. The mean values of the leadership practices used by the nurses were: enable others to act (50.6); encourage the heart (48.2); model the way (46.7); challenge the process (43.3); and inspire a shared vision (43.1). Data analysis also evidenced a correlation between the practice encourage the heart and the variables time of care and employment relationship. Conclusion: The study evidenced the presence of manager nurses exercising moderate leadership, and promoting teamwork, an environment of trust, and a horizontal vision. However, moderate values also reveal managerial aspects to be improved by the leaders by means of organizational strategies and/or tools aimed at best leadership practices.
\end{abstract}

\section{DESCRIPTORS}

Nursing; Leadership; Management; Nursing Service, Hospital; Nursing, Supervisory; Hospital Administration.
Corresponding author:

Silvia Helena Henriques Camelo

Escola de Enfermagem de Ribeirão

Preto, Universidade de São Paulo

Departamento de Enfermagem

Geral e Especializada

Av. Bandeirantes, 3900

CEP 14040-902 - Ribeirão Preto, SP, Brazil

shcamelo@eerp.usp.br
Received: 06/23/2016

Approved: 12/12/2016 


\section{INTRODUCTION}

In the hospital organization there is an expressive contingent of nurses, and the incorporation of new technologies demands increasingly qualified nurses with skills in innovation, creativity, teamwork, and decision-making, which consists of a challenge for even the best nursing leaders. Therefore, regarding the nurse professional of this scenario, the requirements have been related to the care and management skills required in their work. In this sense, leadership is considered a relevant skill for the achievement of the collective and organizational goals of the work organization ${ }^{(1)}$.

Nurses, who are born leaders of the nursing team, should work their potentialities in order to develop the necessary skills related to leadership, particularly in the performance of the communication process and the development of a supportive environment for the exercise of leadership, leading to an improvement in the role model and management style of the nurse in different organizations ${ }^{(2)}$.

A need was also observed for nursing leaders to reflect and self-evaluate their leadership considering perceptions from the team on their adopted actions and practices, as the leadership practices are powerful indicators of the performance of the work of the nursing team ${ }^{(3)}$. However it is important to point out the constant need for a nursing leadership with a transformational approach ${ }^{(4)}$ in health services, especially hospitals.

Nursing managers have been increasingly relating transformational leadership to the innovative behavior of nurses in the work environment, as the managers seek in these professionals a broad knowledge and professional performance in the different organizational aspects ${ }^{(5)}$. From this perspective transformational leadership should be the basis for manager nurses, as it contributes to the quality of care. A model of five practices for exemplary leadership under the influence of transformational leadership ${ }^{(6)}$ was proposed to corroborate these steps: model the way; inspire a shared vision; challenge the process; enable others to act; and encourage the heart. The theoretical model of these practices is internationally recognized for leadership development in different productive segments, and more recently several studies have pointed out its potential for nursing leadership - that is, to assess behaviors associated with the leadership of nurses ${ }^{(7-9)}$.

It is important to point out that this study found that although the leadership practices have a common basis for managers, there is a need for an approach contextualized to the specificity of the health productive and managerial process, particularly in nursing, as it differs from other segments. The nurse is expected to have the appropriate knowledge, skills, and attitudes to effectively perform their managerial functions. In this sense, even without an in-depth knowledge of the theoretical model of the leadership practices ${ }^{(6)}$, leader nurses may develop exemplary leadership practices in their work, such as: telling what people need to do and providing living examples of the ideals they believe (model the way); appeal to the values of individuals and motivate them to take responsibility in an important mission (inspiring a shared vision); challenge conventional practices and create changes (challenging the process); combine collaboration and support to enable the entire group to act (enable others to act); show appreciation and use approaches to motivate people in a positive manner (encouraging the heart). The adopted management and leadership style may provide conditions that facilitate the activities and the creation of an environment of commitment of the team ${ }^{(10)}$. For this reason nursing needs proactive leaders committed to the execution of transformations in the work environment.

It is known that manager nurses working in hospitals develop multiple tasks with a high level of requirements, and such tasks may interfere in the quality of the care depending on how their work is organized and the leadership practices and knowledge adopted. In this sense it is possible to infer that management skills are essential and may be developed and aggregated to the care service by means of leadership practices ${ }^{(6)}$.

In view of the above we introduce the following questions: Which are the leadership practices performed by manager nurses and how often do they develop them in the performance of their activities? Is there any association between the professional and personal profile variables of the nurses and the leadership practices performed by them?

It is necessary to discuss the theme by taking into account that the leadership practices may affect the development of the work of the nurse within the nursing team. In Brazil, until the moment of the data collection of this study no studies identifying the leadership practices of manager nurses in the hospital context were found. Therefore, this investigation aims at deepening the theme by relating leadership practices of hospital manager nurses to their socioprofessional profile. Knowing the leadership practices implemented in the performance of the activities of these professionals is essential for future nurses and managers that intend to work in the hospital area; also, it leads training centers and health institutions to reflect in relation to the strategies used in the training of such workers.

In view of this premise this study aims at assessing the frequency of the leadership practices performed by the manager nurses of hospital institutions and its association to the variables of the socioprofessional profile.

\section{METHOD}

This was a cross-sectional, descriptive, correlational study developed in four hospital institutions (one public and three private) in a city of the state of São Paulo with the participation of 84 manager nurses.

The present study included nurses working as general nursing coordinators, nursing services coordinators (care areas and care support areas), technical managers (TMs), and hospitalization units supervisors and heads working 
in such positions for a minimum period of six months. Manager nurses under legal leave in the period of data collection were excluded.

The model of five practices for an exemplary leadership $^{(6)}$ was the theoretical basis of the categorization and discussion of the content obtained in the data collection.

A two-part instrument was used for data collection. The first one refers to the characterization of the participants in relation to gender, age, year of completion of the nursing graduation, time of employment relationship, time of experience in hospital nursing and in management, qualification for the management position, and area of specialization. The second part consisted of the Leadership Practices Inventory (LPI), validated for use in Brazil, acquired electronically, containing 30 items in the Likert scale format (or referred to by the authors as declaratory behavioral statements) that assesses the leadership practices and distribute them in five domains: model the way; inspire a shared vision; challenge the process; enable others to act; encourage the heart. This instrument is considered an excellent tool for manager nurses that want to develop or improve their skills as transformational leaders ${ }^{(9)}$.

Data collection occurred between June and September 2014 through the self-application of the instrument according to the availability of the participants. Data were entered in spreadsheets of the software Excel 2013, making up an electronic database. Data were entered twice for validation, and this base was transferred to the software IBM Statistical Package for the Social Sciences (SPSS) version 22 and the software $\mathrm{R}$ version 3.0.2. Thus, data were submitted to descriptive statistics and subsequently to inferential analysis with the use of the Mann-Whitney test to compare the results of the LPI and the categorical variables (gender, experience in nursing management, and postgraduate studies). Spearman's test was used to validate the correlation between the results of the LPI and the numeric variables (age, years since completion of graduation, experience in care, employment relationship, and experience in management).

The research project was approved by the Research Ethics Committee of Escola de Enfermagem de Ribeirão Preto at the Universidade de São Paulo under Protocol 045/2014. Resolution 466/2012 in relation to research involving human beings was met.

\section{RESULTS}

Of the manager nurses that participated, 76 (90.5\%) were female. Age ranged between 25 and 62 years, with a mean of 41.2 years; years since graduation ranged between 4 and 38 years, with a mean of 17 years.

Variation between 1.2 and 38.3 years with a mean of 15.5 years was observed in relation to time of work in hospital nursing. Variation between three months and 34.3 years with mean of 15.2 years was observed in relation to the time of employment relationship. The time in the position of nursing services management ranged between six months and 24 years, with a mean of 8.2 years. Thus, only $22(26.2 \%)$ of participants reported to have experience in hospital management prior to accepting the current position; the other $62(73.8 \%)$ had no previous experience.

In relation to postgraduate studies in the management area, only $22(26.2 \%)$ interviewees presented this qualification; 20 had a lato sensu postgraduate degree, specialization, or Master of Business Administration (MBA), and two had stricto sensu graduate master degrees. Another aspect refers to professional improvement, in which 57 (67.9\%) nurses had lato sensu postgraduate education (specialization) in other areas. Table 1 shows the mean, median, and standard deviation of the numeric variables: age; years since graduation; time of experience in care; time of employment relationship; and time of experience in management.

Table 1 - Characterization of the manager nurses participating in the study according to the numeric variables - Ribeirão Preto, SP, Brazil, 2016.

\begin{tabular}{lccc}
\hline Variables & Mean & Median & $\begin{array}{c}\text { Standard } \\
\text { deviation } \\
\text { (SD) }\end{array}$ \\
\hline Age & 41.2 & 40.5 & 8.6 \\
Years since graduation & 17.0 & 16.0 & 7.7 \\
Time of experience in care & 15.5 & 14.5 & 8.2 \\
Time of employment relationship & 15.2 & 14.0 & 8.5 \\
Time of experience in management & 8.2 & 6.0 & 6.1 \\
\hline
\end{tabular}

Table 2 shows the mean, median, and standard deviation values of the answers to the behavioral statements of each one of the five leadership practices related to the adopted leadership model developed by manager nurses of four institutions.

Table 2 - Distribution of mean values, median values, and standard deviation values of the five leadership practices - Ribeirão Preto, SP, Brazil, 2016.

\begin{tabular}{lccc}
\hline Practice & Mean & Median & $\begin{array}{c}\text { Standard } \\
\text { deviation } \\
\text { (SD) }\end{array}$ \\
\hline Model the way & 46.7 & 47.5 & 6.9 \\
Inspire a shared vision & 43.1 & 44.0 & 8.7 \\
Challenge the process & 43.3 & 44.0 & 8.0 \\
Enable others to act & 50.6 & 51.0 & 5.0 \\
Encourage the heart & 48.2 & 50.0 & 7.0 \\
\hline
\end{tabular}

The adoption of the five leadership practices by the manger nurses was observed, with emphasis on the practice enable others to act, with a mean of $50.6 \%$. Data also enabled the description of the behavioral statements and the leadership practice corresponding to the frequency of answers of the participants. It consists in the classification of all of the 30 leadership behaviors from the most frequent to the least frequent. In Table 3, the horizontal lines divide the 10 most frequent behaviors, the frequent ones, and the 10 less frequent ones, consecutively. 
Table 3 - Distribution of the frequency of behavioral statements of the items of the LPI and the respective leadership practice in descending order of frequency (N) and percentage (\%) - Ribeirão Preto, SP, Brazil, 2016.

\begin{tabular}{|c|c|c|c|}
\hline & PRACTICE & $\mathbf{N}$ & $\%$ \\
\hline 14. I treat others with dignity and respect. & Enable & 58 & 69 \\
\hline 4. I develop cooperative relationships among the people I work with. & Enable & 36 & 42.9 \\
\hline 11. I follow through on the promises and commitments that I make. & Model & 35 & 41.7 \\
\hline 30. I give the members of the team lots of appreciation and support for their contributions. & Encourage & 34 & 40.5 \\
\hline 10. I make it a point to let people know about my confidence in their abilities. & Encourage & 32 & 38.1 \\
\hline $\begin{array}{l}\text { 23. I make certain that we set achievable goals, make concrete plans, and establish measurable milestones } \\
\text { for the projects and programs that we work on. }\end{array}$ & Challenge & 30 & 35.7 \\
\hline 5. I praise people for a job well done. & Encourage & 29 & 34.5 \\
\hline 26. I am clear about my philosophy of leadership. & Model & 29 & 34.5 \\
\hline 20. I publicly recognize people who exemplify commitment to shared values. & Encourage & 29 & 34.5 \\
\hline 29. I ensure that people grow in their jobs by learning new skills and developing themselves. & Enable & 27 & 32.1 \\
\hline 9. I actively listen to diverse points of view. & Enable & 26 & 31 \\
\hline 27. I speak with genuine conviction about the higher meaning and purpose of our work. & Inspire & 26 & 31 \\
\hline 24. I give people a great deal of freedom and choice in deciding how to do their work. & Enable & 26 & 31 \\
\hline 17. I show others how their long-term interests can be realized by enlisting in a common vision. & Inspire & 25 & 29.8 \\
\hline 19. I support the decisions that people make on their own. & Enable & 24 & 28.6 \\
\hline 22. I paint the "big picture" of what we aspire to accomplish. & Inspire & 24 & 28.6 \\
\hline 1. I set a personal example of what I expect of others. & Model & 23 & 27.4 \\
\hline 21. I build consensus around a common set of values for running our organization. & Model & 22 & 26.2 \\
\hline 2. I talk about future trends that will influence how our work gets done. & Inspire & 22 & 26.2 \\
\hline 18. I ask "What can we learn?" when things do not go as expected & Challenge & 21 & 25 \\
\hline $\begin{array}{l}\text { 6. I spend time and energy making certain that the people I work with adhere to the principles and stan- } \\
\text { dards that we have agreed on. }\end{array}$ & Model & 21 & 25 \\
\hline 15. I make sure that people are creatively rewarded for their contributions to the success of our projects. & Encourage & 20 & 23.8 \\
\hline 25. I find ways to celebrate accomplishments. & Encourage & 20 & 23.8 \\
\hline 7. I describe a compelling image of what our future could be like. & Inspire & 19 & 22.6 \\
\hline 28. I experiment and take risks, even when there is a chance of failure. & Challenge & 19 & 22.6 \\
\hline 3. I seek out challenging opportunities that test my own skills and abilities. & Challenge & 18 & 21.4 \\
\hline 16. I ask for feedback on how my actions affect other people's performance. & Model & 18 & 21.4 \\
\hline 8. I challenge people to try out new and innovative ways to do their work. & Challenge & 17 & 20.2 \\
\hline 13. I search outside the formal boundaries of my organization for innovative ways to improve what we do. & Challenge & 16 & 19 \\
\hline 12. I appeal to others to share an exciting dream of the future. & Inspire & 14 & 16.7 \\
\hline
\end{tabular}

It is important to mention that the most frequent behavioral leadership statements are related to the leadership practice enable, mainly related to stimulating the collaboration and strengthening of the others. In contrast, the leadership practice inspire is not present in the most frequent behavioral leadership statements executed by professionals, implying that these leaders do not seem to view the future for themselves and others with the purposes of creating possibilities and finding common objectives.
The comparison of the categorical variables gender, experience in management, postgraduation in administration/ management, specialization in other areas, and the scores of the five leadership practices adopted by the nurses through the Mann-Whitney test show that none of the variables presented statistically significant differences with any of the five leadership practices. Table 4 shows the level of significance of these data.

Table 4 - Distribution of the $p$-value of the categorical variables in relation to the scores of the sums of the five leadership practices - Ribeirão Preto, SP, Brazil, 2016.

\begin{tabular}{|c|c|c|c|c|c|}
\hline Variable & $\begin{array}{l}\text { Model } \\
\text { sum } 1\end{array}$ & $\begin{array}{l}\text { Inspire } \\
\text { sum } 2\end{array}$ & $\begin{array}{c}\text { Challenge } \\
\text { sum } 3\end{array}$ & $\begin{array}{l}\text { Enable } \\
\text { sum } 4\end{array}$ & $\begin{array}{c}\text { Encourage } \\
\text { sum } 5\end{array}$ \\
\hline Gender & 0.120 & 0.583 & 0.861 & 0.142 & 0.055 \\
\hline Experience in management & 0.568 & 0.508 & 0.676 & 0.264 & 0.354 \\
\hline Postgraduation in management & 0.795 & 0.146 & 0.376 & 0.959 & 0.614 \\
\hline Postgraduation in other areas & 0.542 & 0.969 & 0.962 & 0.224 & 0.555 \\
\hline
\end{tabular}


The mean values obtained in the sum of each item (behavioral statements) referring to the five leadership practices (domains 1-5) performed by nurses were referred to as sums $1,2,3,4$, and 5 .

The association of the numeric variables and the results of the five leadership practices through the Spearman test showed that two presented statistical significance $(p$ $<0.05)$ with a negative correlation for the practice encourage the heart. Therefore, the correlation between the practice encourage the heart and the variable time of care is -0.217 , while it is -0.310 for the variable time of relationship. Therefore, the longer the time of care, the lower the score of domain 5 , that is, the lower the use of the practice encourage the heart by the nurses. This may also be observed in relation to the time of employment relationship; that is, the longer the time of relationship, the lower the use of this leadership practice.

\section{DISCUSSION}

The mean age of the participants was 41.2 years, corroborating other researchers that reported that the nursing workforce consists predominantly of young professionals ${ }^{(11)}$. The mean value of 15 years of professional experience identified in this study may favor the use of leadership practices that are appropriate to the hospital environment. In this sense, researchers understand that longer time of hospital nursing care provides the nurses with professional maturity, promoting resourcefulness, and broadened critical vision in the face of situations faced in the professional exercise $^{(12)}$ and possibly favoring leadership practices in nursing management.

In terms of employment relationship, it is important to emphasize the fact that most participants had a public employment relationship (79.7\%). This fact may be associated with the observed mean time of employment relationship (15.5 years), showing the permanence of these professionals in the same job for a certain period.

The data of this study showed a small percentage of manager nurses with any type of specialization in the management area. This fact is extremely relevant considering the responsibilities of the position, as it reveals that the institution did not consider this criterion in the choice of the professional for the position. However, the numbers also evidenced little investment by the professionals in their own improvement in the management area.

This study revealed a moderate presence of the five leadership practices in the daily activities of manager nurses. In relation to this, it is known that investments and reviews of the training process of nurses for nursing care management tend to trigger significant changes in the reorganization of their work in the health services ${ }^{(13)}$ and consequently better results for the leadership practices.

Data pointed out the leadership practice enable others to act as the most frequent practice in the work of manager nurses, followed by the practice encourage the heart. These practices were also pointed out in international research with manager nurses ${ }^{(8-9)}$.
In the practice enable others to act, the leader should increase the collaboration, generating trust in the workers and supporting interpersonal relationships, as well as encouraging the development of skills in the team ${ }^{(6)}$. Thus a collaborative leadership enables a better development of a service and establishes mutual respect between the different roles of the professionals ${ }^{(14)}$. Still in relation to this practice, the most frequently behaviors reported by manager nurses were treating others with dignity and respect and developing cooperative relationships between the people that work with them. The nurse adopting this leadership practice participates in the work of their team, providing care in relation to interpersonal communication and relationship of their components. Therefore, the success of the leadership does not depend exclusively on the leader, but also on the relationship and involvement of the team members.

Transformational leaders are sympathetic to individual differences and use communication as an essential tool in the work process so that the members of the team feel a balance of power, being cared for instead of controlled or manipulated ${ }^{(15)}$. Also, nursing managers that provide support and communication by means of transformational leadership contribute in a positive manner to the engagement in the work by nursing professionals, consequently improving the organizational results ${ }^{(16)}$.

Therefore, the professional training of manager nurses should go beyond the skills to execute techniques and the development of knowledge and diversity of experiences in order to lead their teams.

Considering that the health scenario requires technically and scientifically skilled professionals that are able to manage the care, the training of manager nurses with skills to exercise leadership should also be a concern in the training centers. In relation to this, at the international level researchers reveal that the training of health professionals in leadership through didactic modules that allow the application of acquired knowledge has a positive impact on the performance at work and leverages professionals to improve their long-term institutional capacity ${ }^{(17)}$.

It is important to mention that the leadership has few chances to advance in nursing if it is not encouraged by means of innovative attitudes, collective investments, and unity of the whole team, aspects considered positive in the identified leadership practices.

However, still in relation to the adopted practices, manager nurses also pointed out encourage the heart as the second most frequently used practice, showing that they are encouraging the collaboration of everyone, sharing the power, and recognizing the contributions of the team. These facts evidence the personal influence of the leader in the creation of high-quality professional practice environments for nurses ${ }^{(18)}$.

In the evaluation of the performance of their team at the hospital, the manager nurse should take into account the technical and relational aspects involving the performance of their members. In this context leadership emerges as a seemingly desirable skill ${ }^{(19)}$ defined as the ability to 
explicitly articulate the path and the direction, motivating people to focus their efforts on the achievement of the desired objectives ${ }^{(20)}$.

Thus, the leadership of care work teams involves a conscious selection of certain possible actions and behaviors for the leader and for those people influenced by them. Assuming that leadership is a skill that can be learnt, the training of manager nurses in leadership will allow them to be agents of changes in the work process organization of their teams and consequently in the care provided to the users.

It is important to mention that the exercise of the positions of manager, technical manager, coordinators, or leaders of care areas in hospital institutions implies the adoption of the following leadership practices and behaviors: clarifying values; acting in an exemplary manner; visualizing the future; recruiting other leaders; seeking opportunities; experiencing and taking risks; expanding the collaboration; strengthening others; and celebrating successes.

From this perspective the results of this study also lead to a reflection on whether or not the profile of the workers could have impact on the leadership practices adopted in the professional exercise. In the association of the variables of the profiles of the manager nurses and the leadership practices the data showed a negative association between the numeric variables time of care and time of employment relationship, and the practice encourage the heart, implying that in this practice the leader has high expectations about themselves and the others, and that the expectations may be translated into better performances ${ }^{(3)}$.

However, the negative association identified in this study showed that despite the long duration of nursing care and employment relationship in the institution the manager nurses did not adopt the mentioned leadership practice in the work routine. This fact may be associated with the lack of skills by these manager nurses to exercise leadership in aspects related to professional motivation and incentive in relation to the lack of integration between the professionals of the same team.

Therefore, it is important to point out that the leadership practice in which the manager nurse does not encourage and does not stimulate may result in problems in the process of providing care to the users. Due to the attitude of conformation, this leadership is seen as inexperienced in the face of decisions that require evaluation by the professional. Maybe ignorance in relation to the context in certain situations leads manager nurses to this behavior.

On the other hand, this investigation evidences that newly hired nurses and nurses with less time in the area of care seem to be motivated to the leadership practice encourage the heart, that is, they present higher expectations in relation to themselves, to the other members of the team, and with the organization.

The attitude and the profile of the leaders have been changing as the labor market has been increasingly requiring the leadership practice by nurses. These professionals have to lead their work teams with the aim of achieving the best results, so the use of leadership as a skill is essential ${ }^{(21)}$.
From this perspective this study points out an improvement of skills by means of examples by other managers and focused training, although the most common is learning to lead and deal with problems and people specifically in the beginning of their careers.

Therefore, educational institutions should be concerned to train nurses that are able to work with complex technologies in order to meet the demand of the labor market. The knowledge, skills, and abilities for nursing leadership may and should be taught in baccalaureate courses in order to prepare students for leadership roles. However, changing curriculum frameworks does not produce immediate response to graduates or their preparation for specific care environments. Leadership specifically requires education and additional experience ${ }^{(22)}$.

\section{CONCLUSION}

Manager nurses of hospital units have been implementing the five practices of exemplary leadership with moderate frequency, with emphasis on the practice enable others to act. Thus, leaders seek the collaboration of their team by building trust and facilitating the relations by stimulating the participation in the planning and the provision and assessment of care.

This study characterizes the manager nurse as a moderate leader that promotes teamwork, helps to create an environment of trust, shares the power, and values their colleagues. Therefore, this is the type of leader that builds trust with people, leading them to be willing to assume changes.

The fact that the level of frequency of all the practices is moderate means that there are management aspects to be incremented by the leaders that work in the analyzed institutions. In this sense, it is important to point out the need for personal and professional development of manager nurses providing tools and/or strategies for an effective leadership.

The analysis of correlations revealed that the practice encourage the heart presented a negative correlation with the variables time of care and time of employment relationship, showing that despite the time of experience and time of work at the place of work, the manager nurse does not feel stimulated to implement such practice. In this context, managers should create work environments that encourage the leaders to lead their teams. There is also a need to rethink the permanent education of nurses in management positions in order to prepare leaders that work in a positive manner with their teams.

Further studies are necessary to deepen this understanding and provide greater visibility to the profile of the manager nurse and the developed leadership. This study has a limitation in relation to the participant professional category considering that only manager nurses of hospital institutions were included. The present study recommends an expansion of the investigation for the nursing team, that is, the subordinates/non-leaders, for data comparison purposes. This will contribute to the identification of possible similarities or differences in the perceptions of the various professional categories in relation to the leadership practices adopted by the leaders. 
RESUMO

Objetivo: Avaliar a frequência das práticas de liderança executadas pelos enfermeiros gerentes de instituições hospitalares e sua associação às variáveis do perfil socioprofissional. Método: Estudo transversal, descritivo e correlacional, realizado em quatro hospitais de um município do interior paulista. Utilizou-se de questionário sociodemográfico e do instrumento Leadership Practices Inventory. A coleta e a análise de dados foram fundamentadas em um Modelo de Práticas para Liderança exemplar. Resultados: Participaram 84 enfermeiros gerentes. As médias das práticas de liderança utilizadas pelos enfermeiros foram: capacitar os outros a agir (50,6), encorajar o coração $(48,2)$, traçar o caminho $(46,7)$, desafiar o processo $(43,3)$ e inspirar uma visão compartilhada $(43,1)$. Na análise dos dados também se constatou correlação entre a prática encoraje o coração e as variáveis tempo de assistência e vínculo empregatício. Conclusão: $\mathrm{O}$ estudo constatou a presença de enfermeiros gerentes exercendo liderança moderada, promovendo o trabalho em equipe, propiciando um clima de confiança e visão horizontalizada. No entanto, os valores moderados também revelam aspectos gerenciais a serem aprimorados pelos líderes, por meio de ferramentas e/ou estratégias organizacionais em busca de melhores práticas de liderança.

\section{DESCRITORES}

Enfermagem; Liderança; Gerência; Serviço Hospitalar de Enfermagem; Supervisão de Enfermagem; Administração Hospitalar.

\section{RESUMEN}

Objetivo: Evaluar la frecuencia de las prácticas de liderazgo llevadas a cabo por los enfermeros gestores de instituciones hospitalarias y su asociación con las variables del perfil socioprofesional. Método: Estudio transversal, descriptivo y correlacional, realizado en cuatro hospitales de un municipio del interior del Estado de São Paulo. Se utilizó un cuestionario sociodemográfico y el instrumento Leadership Practices Inventory. La recolección y el análisis de datos se fundaron en un Modelo de Prácticas para Liderazgo ejemplar. Resultados: Participaron 85 enfermeros gestores. Los promedios de las prácticas de liderazgo utilizados por los enfermeros fueron: capacitar a los otros a actuar $(50,6)$, animar el corazón $(48,2)$, trazar el camino $(46,7)$, desafiar el proceso $(43,3)$ e inspirar una visión compartida $(43,1)$. En el análisis de datos también se constató correlación entre la práctica "anime el corazón" y las variables tiempo de asistencia y vínculo de empleo. Conclusión: El estudio constató la presencia de enfermeros gestores ejerciendo liderazgo moderado, promoviendo el trabajo en equipo, proporcionando un clima de confianza y visión horizontal. Sin embargo, los valores moderados también desvelaron aspectos de gestión que los líderes deben perfeccionar mediante herramientas y/o estrategias organizativas en búsqueda de mejores prácticas de liderazgo.

\section{DESCRIPTORES}

Enfermería; Liderazgo; Gerencia; Servicio de Enfermería en Hospital; Supervisión de Enfermería; Administración Hospitalaria.

\section{REFERENCES}

1. Dall'Agnol CM, Moura GMSS, Magalhães AMM, Falk MLR, Riboldi CO, Oliveira AP. Motivations, contradictions and ambiguities in the leadership of nurses in management positions in a university hospital. Rev Latino Am Enfermagem [Internet]. 2013 [cited 2016 Aug 31];21(5):1172-8. Available from: http://www.scielo.br/scielo.php?script=sci_arttext\&pid=S0104-11692013000501172

2. Rodrigues EOL, Oliveira JKA, Lopes Neto D, Campos MPA. Avaliação da liderança dos enfermeiros por auxiliares e técnicos de enfermagem segundo o método 360. Revista Gaúcha Enferm [Internet]. 2015 [citado 2016 ago. 31];36(4):29-36. Disponível em: http://seer.ufrgs.br/ index.php/RevistaGauchadeEnfermagem/article/view/50491

3. Eneh VO, Vehviläinen-Julkunen K, Kvist Tarja. Nursing leadership practices as perceived by finnish staff: high ethcs, less feedback and rewards. J Nurs Manag. 2012;20(2):159-69.

4. Mäntynen R, Vehviläinen-Julkunen K, Partanen P, Turunen H, Miettinen M, Kvist T. Changes in transformational leadership and empirical quality outcomes in a finnish hospital over a two-year period: a longitudinal study. Nurs Res Pract. 2014;218069.

5. Weng RH, Huang CY, Chen LM, Chang LY. Exploring the impact of transformational leadership on nurse innovation behaviour: a crosssectional study. J Nurs Manag. 2015;23(4):427-39.

6. Kouzes JM, Posner BZ. LPI: Leadership practices inventory facilitator's guide set. 4th ed. San Francisco: Wiley; 2013.

7. Fardellone C, Click ER. Self-perceived leadership behaviors of clinical ladder nurses. Nurse Leader. 2013;11(6):51-3.

8. Clavelle JT, Drenkard K, Tullai-McGuinness S, Fitzpatrick J. Transformational leadership practices of chief nursing officers in magnet organizations. J Nurs Adm. 2012;42(4):195-201.

9. Heuston MM, Wolf GA. Transformational leadership skills of successful nurse managers. J Nurs Adm. 2011;41(6):248-51.

10. Chavaglia SRR, Coleta MFD, Coleta JAD, Mendes IAC, Trevizan MA. Adaptation and validation of the charismatic leadership socialized scale. Acta Paul Enferm [Internet]. 2013 [cited 2016 Aug 31];26(5):444-54. Available from: http://www.scielo.br/pdf/ape/v26n5/en_ a07v26n5.pdf

11. Barreto IS, Krempel MC, Humerez DC. O Cofen e a enfermagem na América Latina. Enferm Foco [Internet]. 2011 [citado 2016 ago. 31];2(4):251-4. Disponível em: http://revista.portalcofen.gov.br/index.php/enfermagem/article/viewFile/195/131

12. Trigueiro EV, Leite JEL, Dantas DNA, Coura AS, Enders BC. Profile and positioning of the nurse manager regarding to the nursing process. Esc Anna Nery [Internet]. 2014 [cited 2016 Aug 31];18(2):343-9. Available from: http://www.scielo.br/pdf/ean/v18n2/en_14148145-ean-18-02-0343.pdf

13. Santos JLG, Pestana AL, Guerrero P, Meirelles BSH, Erdmann AL. Práticas de enfermeiros na gerência do cuidado em enfermagem e saúde: revisão integrativa. Rev Bras Enferm. 2013;66(2):257-63.

14. Stockham A. Leadership in practice: an analysis of collaborative leadership in the conception of a virtual ward. Nurs Manag. 2016;23(6):30-4.

15. Men LR. Strategic internal communication: transformational leadership, communication channels, and employee satisfaction. Manage Commun Q. 2014;28(2):1-21. 
16. Manning J. The influence of nurse manager leadership style on staff nurse work engagement. J Nurs Adm. 2016;46(9):438-43.

17. Monroe-Wise A, Mashalla Y, O'Malley G, Nathanson N, Seloilwe E, Gachuno O, et al. Training tomorrow's leaders in global health: impact of the Afya Bora Consortium Fellowship on the careers of its alumni. BMC Med Educ. 2016;16(1):241.

18. Lankshear S, Kerr MS, Spence Laschinger HK, Wong CA. Professional practice leadership roles: the role of organizational power and personal influence in creating a professional practice environment for nurses. Health Care Manage Rev. 2013;38(4):349-60.

19. Khoshhal KI, Guraya SY. Leaders produce leaders and managers produce followers: a systematic review of the desired competencies and standard settings for physicians' leadership. Saudi Med J. 2016;37(10).

20. Mathews J. Toward a conceptual model of global leadership. IUP J Organ Behav. 2016;15:38.

21. Balsanelli AP, Cunha ICKO Nursing leadership in intensive care units and its relationship to the work environment. Rev Latino Am Enfermagem [Internet]. 2015 [cited 2016 Aug 31];23(1):106-13. Available from: http://www.scielo.br/pdf/rlae/v23n1/pt_0104-1169rlae-23-01-00106.pdf

22. Joseph ML, Huber DL. Clinical leadership development and education for nurses: prospects and opportunities. Dove Medical Press. 2015;7:55-64. 